\title{
Isolation and Characterization of Agrobacterium tumefaciens Mutants Affected in the Utilization of Octopine, Octopinic Acid and Lysopine
}

\author{
By P. M. KLAPWIJK, P. J. J. HOOYKAAS, H. C. M. KESTER, \\ R. A. SCHILPEROORT AND A. RORSCH \\ Department of Biochemistry, The University, Leiden, The Netherlands
}

(Received 23 February 1976)

\begin{abstract}
SUMMARY
Using an enrichment procedure, mutant strains of Agrobacterium tumefaciens were isolated that lacked the ability to utilize octopine as a nitrogen source. Of 55 such isolates, 44 were unable to utilize several amino acids; the remaining I I strains were altered solely in their ability to utilize octopine, octopinic acid and lysopine. It is concluded that only the latter were plasmid mutations. Among them, there was a high, but no absolute, correlation with avirulence. All strains contained the TI plasmid. All virulent strains showed active transport of octopine when they had previously been grown in medium containing octopine, whereas the avirulent strains failed to show such transport. All the virulent mutants induced tumours containing octopine. The results are discussed in relation to the hypothesis that the genes which code for the octopine synthesizing enzymes in the tumour are of bacterial origin.
\end{abstract}

\section{INTRODUCTION}

The plant tumour, crown gall, can be induced on many dicotyledonous plants after wounding and subsequent infection with Agrobacterium tumefaciens (Smith and Townsend) Conn. The molecular mechanism by which the bacteria evoke the neoplastic growth is still uncertain (Drlica \& Kado, I975; Lippincott \& Lippincott, I975 ; Schilperoort \& Bomhoff, 1975). Tissue culture of bacterium-free tumour tissues has shown that it is characterized by phytohormone-independent growth. In addition, several reports have shown the presence in tumour tissue of the unusual amino-acid derivatives octopine ( $N^{2}$-(D-I-carboxyethyl)-L-arginine: Ménagé \& Morel, I964; Goldmann-Ménagé, 1970), octopinic acid ( $N^{2}$-(D-I-carboxyethyl)-L-ornithine: Ménagé \& Morel, I965), sopine ( $N^{2}$-(D-I-carboxyethyl)-L-lysine : Lioret, I956; Biemann et al., I960) and nopaline ( $N^{2}$-(I,3-dicarboxypropyl)L-arginine : Goldmann, Thomas \& Morel, 1969). Tumours containing octopine also contain octopinic acid and lysopine, whereas nopaline tumours contain only nopaline (GoldmannMénagé, 1970). Whether octopine or nopaline is present depends on which bacterial strain induced the tumour. Agrobacterium tumefaciens strains which induce tumours containing octopine are able to utilize octopine, octopinic acid and lysopine as a nitrogen source, by degrading these compounds to the amino acids and pyruvate; strains which induce nopaline tumours are able to utilize nopaline (Petit et al., 1970; Bomhoff, 1974; Schilperoort \& Bomhoff, 1975).

Recent reports (Watson et al., I975; Bomhoff et al., 1976) indicate that genes determining the specificity of degradation of these amino-acid derivatives, as well as genes necessary for oncogenicity, are located on a large plasmid, the TI plasmid, that is present in all virulent 
strains (Zaenen et al., I974). By transfer of this plasmid, it has been shown that the type of amino-acid derivative synthesized in the tumour depends on the type of plasmid and not on the bacterial chromosome (Bomhoff et al., 1976). Morel (I97I) explained these results by assuming that bacterial genes are transferred to the plant cells during the induction of a tumour (Morel, I971). His hypothesis can now be extended to the transfer of plasmid genes. It is noteworthy that the octopine dehydrogenase of Pecten maximus L. catalyses both synthesis and degradation (Van Thoai \& Robin, I96I). To determine whether the same is true for the bacterial and tumour enzymes, studies will have to be made with purified enzymes. To date, nucleic-acid studies have not detected plasmid DNA in sterile tumour tissue (Chilton et al., I975; Dons, 1975), although it is conceivable that there are too few bacterial genes present to be detected.

We have studied Morel's (I97I) hypothesis that the synthesis of octopine in crown gall cells is coded by $A$. tumefaciens genes in these cells, by isolating $A$. tumefaciens mutants that cannot use octopine as a nitrogen source. If octopine synthesis is caused by a bacterial gene that, in the bacterial cell, codes for an enzyme catalysing octopine breakdown, i.e. an octopine oxidase, then lesions in that gene should give rise to avirulent mutants or mutants which induce tumours that do not contain octopine.

\section{METHODS}

Bacterial strain. The parental $A$. tumefaciens strain used in this study was $\mathrm{B}_{6} \mathrm{~S}_{3}$ (Vervliet et al., 1975); numbered LBA2 in our collection. All incubations were carried out at $29^{\circ} \mathrm{C}$.

Media. NB was used as a rich medium and contained $\left(\mathrm{g}^{-1}\right)$ : Difco nutrient broth, $8 \cdot 0$; Difco yeast extract, $5^{\circ} ; \mathrm{NaCl}, 5^{\circ} 0$. LC, used in phage typing and agrocin tests, contained $\left(\mathrm{g} \mathrm{l}^{-1}\right)$ : Difco tryptone, I0.0; Difco yeast extract, $5 \cdot 0 ; \mathrm{NaCl}, 8 \cdot 0 . \mathrm{SM}$ was used as a minimal medium (Klapwijk et al., 1975). For the determination of growth on the different amino acids, ammonium sulphate was omitted from the minimal medium (called SM-N) and one of the following was added $\left(\mathrm{mg}^{-1}\right)$ : arginine, 70 ; octopine, I00; lysopine, I 80 ; octopinic acid, I60; other amino acids, 200. When required, media were solidified by $\mathrm{I} \cdot 8 \% \mathrm{w} / \mathrm{v})$ Difco Bacto-agar or, when testing for nitrogen source utilization, by $2.6 \%$ (w/v) Difco Special Agar Noble.

Phages. The phage typing was done as described by van Larebeke et al. (1975) using their phage strains. Exclusion of phage API (Schell, 1975) was determined by titrating serial dilutions on exponentially growing bacteria using the soft-agar technique. The top layer contained LC plus $0.6 \%(\mathrm{w} / \mathrm{v})$ agar. Several virulent and avirulent wild-type strains were included in every test as controls.

Agrocin sensitivity. Sensitivity to agrocin produced by Agrobacterium radiobacter sioo5 was determined as described by Engler et al. (1975), but clearer results were obtained using the LC medium.

Mutagenesis. $N$-Methyl- $N^{\prime}$-nitro- $N$-nitrosoguanidine (NTG) mutagenesis was carried out as described formerly (Klapwijk et al., 1975). Ethyl methanesulphonate (EMS) mutagenesis was carried out for $2 \mathrm{~h}$, as described by Lin, Lerner \& Jorgensen (1962), using EMS at a final concentration of $0.06 \mathrm{M}$ in $0.2 \mathrm{M}$-Tris/ $\mathrm{HCl}$ containing $\left(\mathrm{g} \mathrm{l} 1^{-1}\right): \mathrm{K}_{2} \mathrm{HPO}_{4},{ }_{10} \cdot 5 ; \mathrm{KH}_{2} \mathrm{PO}_{4}$, $4.5 ;\left(\mathrm{NH}_{4}\right)_{2} \mathrm{SO}_{4}, \mathrm{I} \cdot 0 ; \mathrm{pH} 7 \cdot 5$. After mutagenesis, bacteria were incubated overnight in SM to allow segregation of the mutations.

Enrichment procedure and mutant isolation. A mutagenized culture was washed twice in $\mathrm{SM}-\mathrm{N}$, resuspended at $2 \times 10^{8}$ organisms $\mathrm{ml}^{-1}$ in SM-N plus octopine and incubated for I 50 min. Carbenicillin and lysozyme were then added (Klapwijk et al., I975), and incubation 

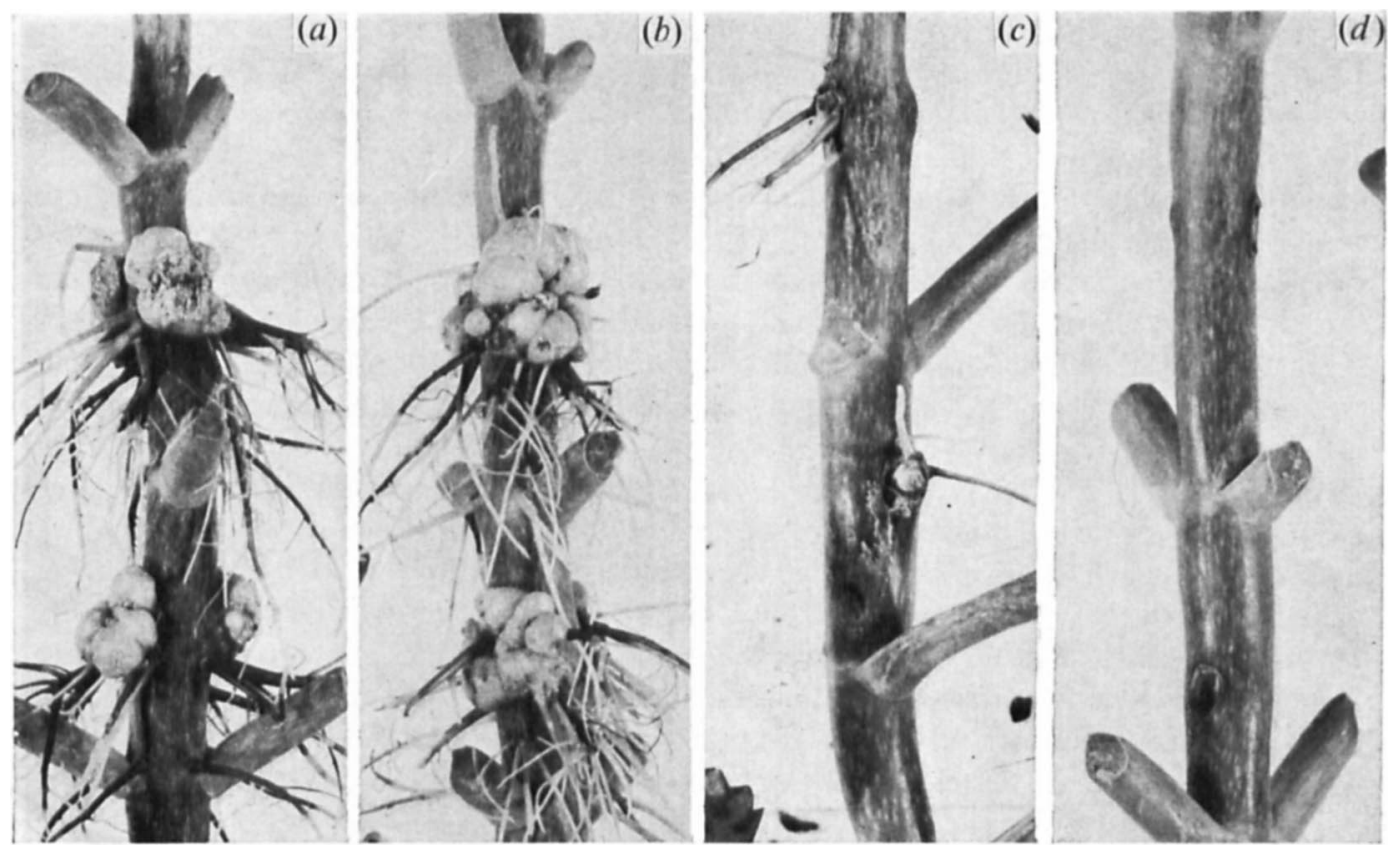

Fig. I. Results of virulence tests with representative Uad - mutants ; 8 weeks after infection. (a) Wild type LBA2, strong tumour formation ; (b) Uad - mutant LBA I04, strong tumour formation ; (c) Uad mutant LBA I08, weak tumour formation; $(d) \mathrm{Uad}^{-}$mutant LBAI 02, no tumour formation.

was continued for 4 to $5 \mathrm{~h}$ till lysis occurred. The bacteria were collected by centrifuging, washed with water, resuspended in SM and grown to the stationary phase. This enrichment procedure was repeated twice. Suitable dilutions were plated on SM, and after 2 days the colonies were replica-plated to SM-N plus octopine and to SM. Suspected mutant colonies were purified, and tested by inoculating a loopful of a suspension of the colony in $0.5 \mathrm{ml}$ liquid SM-N plus octopine in a culture tube. After 4 days' incubation with shaking, the tests were judged on the basis of visible growth and by spotting a $5 \mu \mathrm{l}$ sample on Whatman $3 \mathrm{MM}$ paper and staining for guanidine-positive compounds using the phenanthrenequinone reagent described by Yamada \& Itano (1966). When growth was observed, the guanidine test was always negative. All tests were repeated in separate experiments with the same results.

Virulence tests. For good quantitative reproducibility, Kalanchoë daigremontiana (Hamet $\&$ Perrier) plants were used following the procedure of Bomhoff et al. (1976). A culture grown overnight in NB was inoculated 24 to $26 \mathrm{~h}$ after wounding the stems. The plants were allowed to develop tumours while kept in a greenhouse at approximately $25{ }^{\circ} \mathrm{C}$ and $70 \%$ relative humidity for 8 to ro weeks ; and were scored for strong, weak, or no tumour formation (Fig. I).

Detection of octopine in tumours. The extraction of tumours, subsequent high-voltage electrophoresis and staining have been described (Schilperoort \& Bomhoff, 1975). To prevent oxidation of polyphenols, O.I mM-I,4-dithiothreitol (DTT) was included in the extraction mixture.

Qualitative plasmid isolation was carried out using alkaline sucrose gradient centrifugation of alkaline lysates prepared from bacteria labelled with $\left[{ }^{3} \mathrm{H}\right]$ thymidine (Ledeboer et al., 1976). 
Revertants were isolated by plating $0^{\circ} \mathrm{I} \mathrm{ml}$ of a washed suspension of $10^{9} \mathrm{bacteria} \mathrm{ml}^{-1}$ on SM-N plus octopine. Reversion was stimulated by placing a crystal of NTG or a Io $\mu \mathrm{l}$ drop of 12 M-EMS on the centre of the plate.

Determination of octopine and arginine uptake. Cultures were grown overnight in SM; when induction of the octopine system was required, octopine (IOO $\left.\mathrm{mg}^{-1}\right)$ was added. The cultures were then diluted with an equal volume of fresh SM and incubated for another $5^{\circ}$ min. Bacteria were harvested by centrifuging and resuspended in SM-N at $5 \times 10^{8}$ organisms $\mathrm{ml}^{-1}$. A portion $(2 \mathrm{ml})$ of this bacterial suspension was added to $30 \mu \mathrm{l}\left[{ }^{3} \mathrm{H}\right.$ ]octopine (4I8 $\mu \mathrm{g} \mathrm{ml}^{-1}$; I $\left.44 \mu \mathrm{Ci} \mathrm{mg}^{-1}\right)$. Samples $(250 \mu \mathrm{l})$ were taken after o, I, 2, 4 and $6 \mathrm{~min}$, immediately diluted with $5 \mathrm{ml} 0.9 \%(\mathrm{w} / \mathrm{v}) \mathrm{NaCl}$, filtered on a Millipore filter $(0.45 \mu \mathrm{m}$ pore size) and washed with $20 \mathrm{ml} 0.9 \% \mathrm{NaCl}$. The filters were dried and counted in toluene containing $0.4 \%$ 2,5-diphenyloxazole (PPO) using a liquid scintillation counter. Uptake of $\left[{ }^{3} \mathrm{H}\right]$ arginine was determined in the same way, but using $\mathrm{I} \times \mathrm{IO}^{8}$ bacteria $\mathrm{ml}^{-1}$, and arginine at $660 \mu \mathrm{g} \mathrm{ml}^{-1}\left(200 \mu \mathrm{Ci} \mathrm{mg}^{-1}\right)$. The dry weight of $10^{8}$ bacteria grown in SM was $30 \mu \mathrm{g}$.

Chemicals. $\left[{ }^{3} \mathrm{H}\right]$ Octopine was synthesized from $L-\left[\beta-{ }^{3} \mathrm{H}\right]$ arginine and 2 -bromopropionic acid following the procedure of Bomhoff (1974). The product was purified by column chromatography using Bio-Rad anion exchanger AG-2-X8 and subsequent preparative paper electrophoresis as previously described (Bomhoff, 1974; Schilperoort \& Bomhoff, 1975). The final product was more than $96 \%$ pure, and was mixed with commercial octopine to obtain the desired specific activity.

$\left[{ }^{3} \mathrm{H}\right]$ Arginine was obtained from New England Nuclear ; $\mathrm{D}(+)$-octopine, $\mathrm{D}(+)$-octopinic acid and lysozyme (eggwhite, grade I) were from Sigma. Lysopine was a generous gift from Dr B. Lejeune, Orsay, France. NTG was obtained from Pfaltz \& Bauer, New York, U.S.A. ; EMS from OCS, Bussum, The Netherlands; carbenicillin from Beecham, Heppignies, Belgium; and PPO and DTT were from Merck. All other chemicals were of standard analytical grade.

Symbols. The symbol Uad - is used to designate strains that do not utilize the amino-acid derivatives octopine, lysopine and octopinic acid, but are not affected in their utilization of the corresponding amino acids.

\section{RESULTS}

From several mutagenized cultures of $A$. tumefaciens LBA2, 55 strains were isolated that did not grow when ammonia was replaced as the nitrogen source by octopine. As a control, all isolates were tested with a series of phages, and had the same immunity pattern as LBA2. Like the parental strain they were sensitive to the agrocin of $A$. radiobacter 51005 .

\section{Mutants altered in amino-acid metabolism}

Of the 55 strains isolated, 44 could not utilize several amino acids. Negative results were obtained with alanine, arginine, citrulline, ornithine, glutamate, glycine, histidine, lysine, phenylalanine, proline and serine; and, of the amino acids tested, only glutamine was utilized. This type of mutant grew very well on SM, which contains ammonia as a nitrogen source, as well as on the rich medium NB. Uptake of $\left[{ }^{3} \mathrm{H}\right]$ octopine and $\left[{ }^{3} \mathrm{H}\right]$ arginine was quite normal (data not shown). In fact, when octopine was added in the presence of excess ammonium sulphate, it was totally degraded. This type of mutation affected virulence; of the 44 isolates only one induced a normal tumour, while 13 were weakly virulent and 30 avirulent. This low virulence might be due to bacterial nitrogen starvation and inhibition of protein synthesis in the wound site. To test this, the mutant bacteria were inoculated into the plant in NB and after 4,8 and $\mathrm{I} 2 \mathrm{~h}$ the wound was filled with a $0.0 \mathrm{I} \%$ ammonium 
Table I. Summary of the properties of I I $\mathrm{Uad}^{-}$mutants and of the parental strain $\mathrm{LBA} 2$

\begin{tabular}{|c|c|c|c|c|c|c|c|c|}
\hline LBA strain & $\begin{array}{l}\text { Mutation } \\
\text { induced } \\
\text { with }\end{array}$ & $\begin{array}{c}\text { Growth on } \\
\text { octopine }\end{array}$ & $\begin{array}{l}\text { Growth on } \\
\text { arginine }\end{array}$ & $\begin{array}{l}\text { Uptake of } \\
\text { octopine }\end{array}$ & $\begin{array}{l}\text { Tumour } \\
\text { induction, } \\
\text { Kalanchoë }\end{array}$ & $\begin{array}{l}\text { Presence of } \\
\text { octopine in } \\
\text { tumour }\end{array}$ & $\begin{array}{l}\text { Reversion } \\
\text { to Uad }+\end{array}$ & $\begin{array}{c}\text { Presence } \\
\text { of plasmid }\end{array}$ \\
\hline IOI & NTG & - & + & + & Weak & + & - & + \\
\hline 102 & NTG & - & + & - & None & & - & + \\
\hline 103 & NTG & - & + & - & None & & - & + \\
\hline 104 & NTG & - & + & + & Strong & + & + & ND \\
\hline $105^{*}$ & EMS & - & + & - & None & & - & + \\
\hline $106^{*}$ & EMS & - & + & - & None & & - & + \\
\hline 107 & EMS & - & + & - & None & & - & + \\
\hline 108 & NTG & - & + & + & Weak & + & + & ND \\
\hline I09* & NTG & - & + & + & Strong & + & + & ND \\
\hline I IO* & NTG & - & + & + & Strong & + & + & ND \\
\hline I I I & NTG & - & + & + & Strong & + & + & ND \\
\hline 2 & & + & + & + & Strong & + & & + \\
\hline
\end{tabular}

ND, Not determined.

* Although it is statistically improbable 105 may be isogenic with 106, and I09 with I Io.

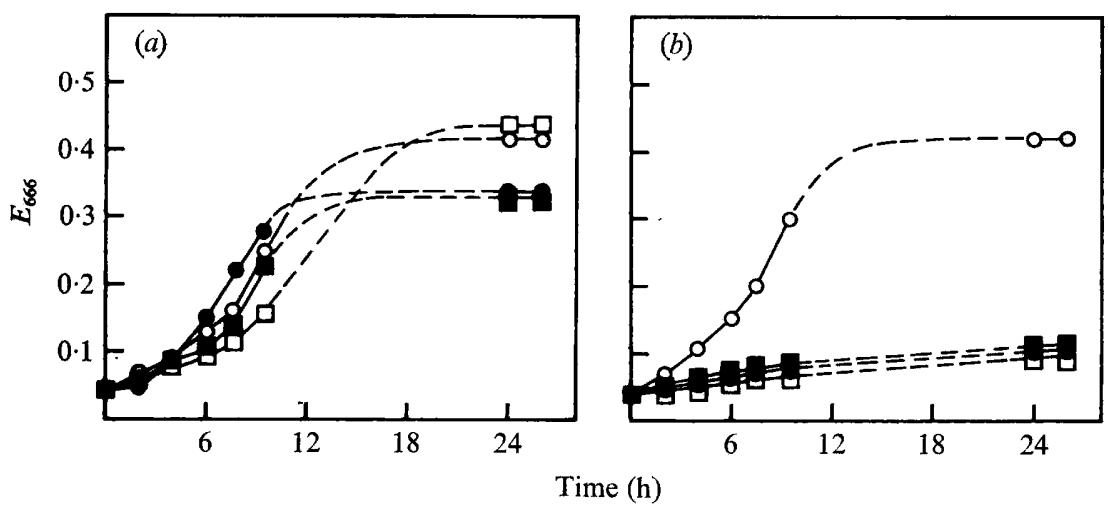

Fig. 2. Growth curves of $(a)$ LBA2 and (b) Uad - mutant LBAI 04 on SM-N media containing (mg $\left.1^{-1}\right)$ : $\bigcirc$, arginine $70 ; \bullet$, octopine $I 00 ; \square$, lysopine I $80 ; \mathbf{w}$, octopinic acid I60. The bacteria were pregrown in SM containing octopine ( $\left.100 \mathrm{mg}^{-1}\right)$, washed twice and resuspended in the media to give an $E_{666}$ of 0.04, corresponding to $10^{8}$ organisms $\mathrm{ml}^{-1}$.

sulphate solution in water. In the three avirulent strains tested, this treatment led to weak tumour induction. The mutation in this type of mutant seems to influence ammonia assimilation in general and is not specific for octopine breakdown. For these reasons, we did not study these 44 strains further.

\section{Octopine mutants}

The properties of the other I I strains are summarized in Table I. Loss of the ability to utilize octopine was always accompanied by loss of the ability to grow on lysopine and octopinic acid, but growth on the corresponding amino acids arginine, lysine and ornithine was not affected (Fig. 2). The revertants which could be isolated by selection of a Uad ${ }^{+}$ phenotype also grew on lysopine and octopinic acid. In five of the I I mutants, virulence was lost. This was rather a high proportion, in view of our finding that after NTG treatment of strain LBA2 no more than $5 \%$ of the prototrophic colonies were avirulent, and after EMS treatment, no more than I $\%$. Of the six virulent $\mathrm{Uad}^{-}$strains, two were weakly virulent; 

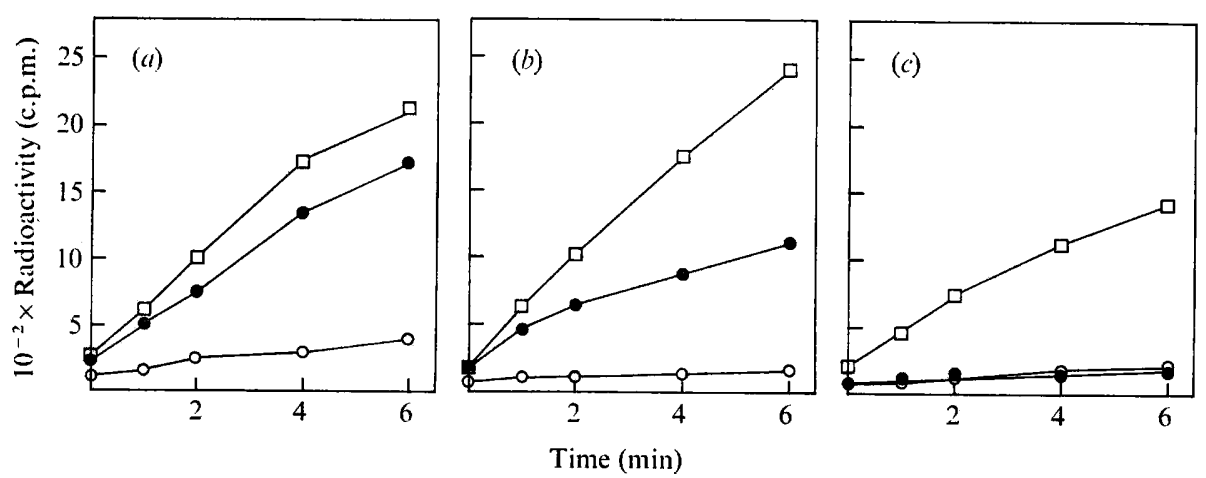

Fig. 3. Uptake of $\left[{ }^{3} \mathrm{H}\right]$ octopine and $\left[{ }^{3} \mathrm{H}\right]$ arginine by $(a)$ LBA2, $(b)$ LBAIO9, and (c) LBAIO2, measured as described in Methods. $\bigcirc,\left[{ }^{3} \mathrm{H}\right]$ octopine uptake in uninduced cultures; $\mathbf{0},\left[{ }^{3} \mathrm{H}\right]$ octopine uptake in cultures induced by growth with octopine $\square,\left[{ }^{3} \mathrm{H}\right]$ arginine uptake.

but the weak virulence of one of the latter (LBAI08) seems to have nothing to do with the octopine mutation, because after reversion to $\mathrm{Uad}^{+}$the strain was still weakly virulent. All the strains carrying revertible mutations were virulent, indicating that these were point mutations. The other strains did not revert, even with NTG or EMS. To exclude the possibility that tumour induction with the virulent strains was due to revertants in the inoculated population, we performed several reconstruction experiments with artificial mixtures of virulent wild-type and avirulent mutant bacteria. These experiments showed that in our Kalanchoë daigremontiana test system, tumour induction only occurred when the ratio of virulent to avirulent bacteria was higher than $\mathrm{Io}^{-3}$; whereas the frequency of revertants in the cultures used for inoculating the plants was not higher than $\mathrm{IO}^{-6}$. In addition we tried to isolate $\mathrm{Uad}^{+}$revertants from the tumours induced by the $\mathrm{Uad}^{-}$mutants, but without success.

To study whether the mutation affected the octopine permease or the octopine oxidase function, we compared the uptake of $\left[{ }^{3} \mathrm{H}\right]$ octopine with that of $\left[{ }^{3} \mathrm{H}\right]$ arginine. The virulent strains I0I, I04, I08, I09, I I0 and II I all showed active transport of octopine when the bacteria had previously been grown in SM containing octopine; whereas the others did not (Fig. 3). Like the parental strain, every virulent $\mathrm{Uad}^{-}$strain induced a tumour containing octopine as shown by high-voltage electrophoresis of tumour extracts. The same results were obtained in several experiments.

\section{Plasmids}

The avirulent strains were examined for plasmid DNA, since loss of the plasmid could explain the linked loss of octopine degradation and virulence. Using alkaline sucrose gradients (Ledeboer et al., I976), all Uad-strains were shown to harbour a plasmid having a sedimentation velocity indistinguishable from that of the plasmid of LBA2. Thus, if a deletion in the plasmid is responsible for the simultaneous loss of virulence and octopine degradation, it must be a small one.

The exclusion of phage API, which is also a plasmid-coded property (Schell, I975), was still exhibited in all I I mutant strains.

\section{DISCUSSION}

The isolation of octopine mutants by the enrichment procedure described is inefficient compared with the isolation of auxotrophic mutants. The main cause for this may be that a 
nitrogen source is not really suitable as a genetical marker in $A$. tumefaciens because of the amount of background growth, especially on plates. In theory it should be possible to use arginine-requiring auxotrophs to introduce the octopine mutation (because these strains can be supplemented with octopine), and so treat cctopine utilization like an amino-acid requirement. However, the arginine mutants we have isolated were not suitable because they grew very poorly on rich medium and induced tumours weakly or not at all. Thus we use octopine as the nitrogen source.

Most of our isolates were affected in their utilization of several amino acids. We believe that this type of mutation affects basic metabolism, and is chromosomal, so we focused our attention on the I I mutants that were affected only in the utilization of octopine. It might be possible to avoid the isolation of mutants affected in the utilization of amino acids by growing the mutagenized cultures on arginine or another amino acid instead of ammonia.

No mutants were isolated that had lost their plasmid, confirming the observation of Schell (personal communication) that, for some unknown reason, LBA2 never loses its plasmid. Biochemical investigations have suggested that octopine, lysopine and octopinic acid are degraded by the same inducible enzyme system, although this could not be proved, because the membrane-bound enzyme activity could not be purified (Jubier, 1972). The uptake of these three compounds is carried out by a single inducible permease system, which is different from the arginine permease (Klapwijk, unpublished observations). These observations are confirmed by the behaviour of our mutants, which showed an absolute linkage between octopine, lysopine and octopinic acid degradation. The finding is of interest because, in tumours, the synthesis of the three compounds also seems to be coupled (GoldmannMénagé, I970).

The utilization of octopine as a nitrogen source proceeds in three steps : (i) active transport across the membrane by the octopine permease; (ii) splitting into arginine and pyruvate by the octopine oxidase; and (iii) transfer of the nitrogen from arginine to other amino acids. All octopine mutants were like the wild type in step (iii), because they grew on arginine. After an induction period, the virulent strains (LBAIOI, I04, I08, I09, IIO and III) were unaffected in the uptake of $\left[{ }^{3} \mathrm{H}\right]$ octopine, so they were probably blocked in the octopine oxidase function.

We cannot yet be sure about the location of the mutation. Although previous studies (Bomhoff et al., 1976) indicated that the specificity and the activity of the enzyme system for octopine utilization is coded for by the TI plasmid, we cannot exclude the possibility that all six strains have a chromosomal mutation resulting in the Uad-phenotype, while the structural gene for octopine oxidase is not affected. At the moment there is no evidence for such a factor. Only plasmid transfer could provide formal proof, but recipients can only be selected when carrying the $\mathrm{Uad}^{+}$plasmid. The six $\mathrm{Uad}^{-}$mutant strains were still able to induce tumours containing octopine, and so the capacity of the bacterium to break down octopine is not a prerequisite for its capacity to induce tumours. Furthermore, even if the genes that promote octopine synthesis in the plant-tumour cells are of bacterial origin, they are probably not identical with the octopine oxidase genes proposed by Morel (197I). Our results do not permit a definite conclusion as to whether or not gene transfer occurs during tumour induction.

The strains LBAI02, I03, I05, I06 and 107 were avirulent, did not revert, did not take up octopine, still carried the TI plasmid and exhibited phage API exclusion. We believe this indicates that certain genes required for virulence are closely linked to octopine genes and were probably simultaneously lost by a small deletion in the p'asmid. An alternative explanation is that the octopine permease is involved in tumour induction, since all the 
avirulent strains lack this activity. If this were the case, mutants lacking the octopine permease might be avirulent because induction of some repressed plasmid functions needed for virulence cannot take place. We were not able to test this possibility as conditional or reverting permease mutants were not available.

We propose the use of the symbol $u a d A$ for the octopine oxidase gene, $u a d B$ for the octopine permease gene and $u a d R$ for the octopine regulatory gene.

We are grateful to Dr A. M. Ledeboer for carrying out the plasmid detection and to Dr B. Lejeune for his gift of lysopine. These investigations were partly been sponsored by the Netherlands Foundation for Chemical Research (SON) with financial aid from the Netherlands Organization for the Advancement of Pure Research (ZWO).

\section{REFERENCES}

Biemann, K., Lioret, C., Asselineau, K., Lederer, E. \& Polonski, J. (1960). Sur la structure chimique de la lysopine, nouvel acide aminé isolé de tissu de crown-gall. Bulletin Société Chimique Biologique 42, 979991.

BомноF, G. H. (1974). Studies on crown gall - a plant tumour. Investigations on protein composition and on the use of guanidine compounds as a marker for transformed cells. Thesis, University of Leiden, The Netherlands.

Bomhoff, G. H., KlapwiJk, P. M., Kester, H. C. M., Schilperoort, R. A., Hernalsteens, J. P. \& Schell, J. (1976). Octopine and nopaline: synthesis and breakdown genetically controlled by a plasmid of Agrobacterium tumefaciens. Molecular and General Genetics 145, I77-181.

Chilton, M. D., Farrand, S. K., Eden, F., Currier, T. C., Bendich, A. T., Gordon, M. P. \& Nester, E. W. (1975). Is there foreign DNA in crown gall tumor DNA ? In The Modification of the Information Content of Plant Cells, pp. 297-3 I I. Edited by R. Markham, D. R. Davies, D. A. Hopwood and R. W. Horne. Amsterdam : North Holland/American Elsevier.

Dons, J. J. M. (1975). Crown gall-a plant tumor. Investigations on the nuclear DNA content and on the presence of Agrobacterium tumefaciens and phage PS8 DNA in crown gall cells. Thesis, University of Leiden, The Netherlands.

Drlica, K. A. \& Kado, C. I. (1975). Crown gall tumors : are bacterial nucleic acids involved ? Bacteriological Reviews 39, I86-196.

Engler, G., Holsters, M., van Montagu, M., Schell, J., Hernalsteens, J. P. \& Schilperoort, R. A. (1975). Agrocin 84 sensitivity, a plasmid determined property. Molecular and General Genetics $\mathbf{1 3 8}$, 345-349.

Goldmann, A., Thomas, D. W. \& Morel, G. (I969). Sur la structure de la nopaline métabolite anormal de certaines tumeurs de crown gall. Comptes rendus hebdomadaire des séances de l'Académie des sciences 268, 852-854.

Goldmann-MÉnAGÉ, A. (1970). Recherches sur la métabolisme azoté des tissus de Crown gall cultivés 'in vitro'. Thesis, Université de Paris, France.

JUBIER, M. F. (1972). Degradation of lysopine by an inducible membrane-bound oxidase in Agrobacterium tumefaciens. FEBS Letters 28, I 29-1 32.

KlapwiJk, P. M., DE Jonge, A. J. R., Schilperoort, R. A. \& Rörsch, A. (I975). An enrichment technique for auxotrophs of Agrobacterium tumefaciens using a combination of carbenicillin and lysozyme. Journal of General Microbiology 91, I77-182.

Larebeke, N. van, Engler, G., Holsters, M., van den Elsacker, S., Zaenen, I., SChilperoort, R. A. \& SCHELL, J. (I974). Large plasmid in Agrobacterium tumefaciens essential for crown gall inducing ability. Nature, London 252, 169-I 70.

Larebeke, N. van, Genetello, Ch., Schell, J., Schilperoort, R. A., Hermans, A. K., Hernalsteens, J. P. \& VAn MonTagu, M. ( I975). Acquisition of tumor inducing ability by non-oncogenic Agrobacteria as a result of plasmid transfer. Nature, London $255,742-743$.

Ledeboer, A. M., Krol, A. J. M., Dons, J. J. M., Spier, F., Schilperoort, R. A., Zaenen, I., van LareBEKE, N. \& SCHELL, J. (I976). On the isolation of T.I. plasmid from Agrobacterium tumefaciens. Nucleic Acids Research 3, 449-464.

Lin, E. C. C., LeRnER, S. A. \& JoRgensen, S. E. (I962). A method for isolating constitutive mutants for carbohydrate catalyzing enzymes. Biochimica et biophysica acta 6o, 422-424.

LiORET, C. (1956). Sur la mise en évidence d'un acide aminé non identifié particulier aux tissus de crown-gall. Bulletin de la Société française de physiologie végétale 2, 76. 
Lippincott, J. A. \& Lippincolt, B. B. (1975). The genus Agrobacterium and plant tumorigenesis. Annual Review of Microbiology 29, 377-405.

Ménagé, A. \& Morel, G. (1964). Sur la présence d'octopine dans les tissus de crown-gall. Comptes rendus hebdomadaire des séances de l'Académie des sciences 259, 4795-4796.

MÉnagé, A. \& Morel, G. (1965). Sur la présence d'une acide aminé nouveau dans les tissus de crown-gall. Comptes rendus hebdomadaire des séances de l'Académie des sciences 261, 200 I-2002.

Morel, G. (1971). Déviations du métabolisme azoté des tissus de crown gall. In Les Cultures de Tissus de Plantes, pp. 463-47I. Colloques Internationaux du C.N.R.S. Edited by G. Morel. Paris : Editions de l'Institut National de la Recherche Agronomique.

Petit, A., Delhaye, S., Tempé, G. \& Morel, G. (1970). Recherches sur les guanidines des tissus de crown gall. Mise en évidence d'une relation biochimique specifique entre les souches d'Agrobacterium tumefaciens et les tumeurs qu'elles induisent. Physiologie Végétale 8, 205-2 I 3.

SCHELL, J. (1975). The role of plasmids in crown-gall formation by Agrobacterium tumefaciens. In Genetic Manipulations with Plant Material, pp. I63-18I. Edited by L. Ledoux. New York: Plenum Press.

SChilperoort, R. A. \& Bomhoff, G. H. (1975). Crown gall : a model for tumor research and genetic engineering. In Genetic Manipulations with Plant Material, pp. I41-162. Edited by L. Ledoux. New York : Plenum Press.

Van Thoai, N. \& Robin, Y. (I96I). Métabolisme des dérivés guanidylés. IX. Biosynthèse de l'octopine : étude du méchanisme de la réaction et de quelques propriétés de l'octopine synthetase. Biochimica et biophysica acta 52, $22 \mathrm{I}-233$.

Vervliet, G., Holsters, M., Teuchy, H., van Montagu, M. \& Schell, J. (I975). Characterization of different plaque forming and defective temperate phages in Agrobacterium strains. Journal of General Virology 26, 33-48.

Watson, B., Currier, T. C., Gordon, M. P., Chilton, M. D. \& Nester, E. W. (1975). Plasmid required for virulence of Agrobacterium tumefaciens. Journal of Bacteriology 123, 255-264.

Yamada, S. \& Itano, H. A. (I966). Phenantrene quinone as an analytical reagent for arginine and other mono-substituted guanidines. Biochimica et biophysica acta 130, 538-540.

Zaenen, I., van Larebeke, N., Teuchy, H., van Montagu, M. \& Schell, J. (1974). Supercoiled circular DNA in crown gall inducing Agrobacterium strains. Journal of Molecular Biology 86, 109-1 27. 